\title{
Main Fundamentals of Economic Judiciary of Ukraine
}

\author{
Vadym Koverznev $^{1}$
}

\begin{abstract}
The article deals with the principles of judicial proceedings by economic courts of Ukraine and their legal nature is disclosed. The relation between the concepts of "jurisdiction" and "justice" is determined; the author formulates the principle of the rule of law and outlines its main elements; the legal nature of the principle of justice and its variants is disclosed; criteria for determining the reasonableness of the terms of the court's consideration of the case are proposed; it is substantiated that the enforcement of the judgment is the final stage of the administration of justice and one of the main criteria for determining the effectiveness of judicial protection of individual rights. The author has proved that the current economic procedural legislation of Ukraine is based on the international legal principles of activity of judicial bodies and ways of its improvement are suggested.
\end{abstract}

Keywords: fundamentals of economic judiciary, jurisdiction, justice, the rule of law, ratability, binding nature of court decisions

\section{Introduction}

In this article, the issue of implementation of international legal foundations of judicial protection of the rights of participants of economic relations as a guarantee of sustainable development of Ukraine, the first part of which is published in the European Journal of Sustainable Development $(2019,8,3)$,is continued to be researched.

In the previous part of the scientific research, basic principles of the activity of the judiciary were systematized, which are formulated in various governing international legal acts and their legal nature is disclosed.

This article is devoted to the legal analysis of the national principles on which the economic judiciary of Ukraine is based, for their compliance with international principles, to identify shortcomings and substantiate proposals to improve the administration of justice.

\section{Principles of Economic Litigation in Ukraine and Their Characteristics}

The principles of law are the starting ideas that determine the most important patterns and foundations of this type of law, they are one-of-a-kind with the essence of law and are its main features, in this case, they are determined by the versatility, the higher imperative and the overall importance [11].

Principles of commercial procedural law belong to the sectorial principles (principles) and are aimed at ensuring the proper administration of economic litigation.

Pursuant to the part one of Article 2 of the Commercial Procedure Code of Ukraine (hereinafter referred to as the CPC), the task of economic litigation is the fair, impartial 
and timely resolution of disputes by a court, business-related issues and other matters within the jurisdiction of an economic court, in order to effectively protect the violated, unrecognized or disputed rights and legitimate interests of individuals and legal entities, the state.

By the order of Section III of the same article, one of the main fundamentals (principles) of economic litigation is:

1) rule of law;

2) equality of all participants in the lawsuit before the law and the court;

3) publicity and openness of the trial and its full fixation by technical means;

4) competitiveness of the parties;

5) permissive rule;

6) ratability;

7) binding nature of court decisions;

8) ensuring the right to review the case;

9) ensuring the right to appeal against a court decision in the cases specified by law;

10) reasonableness of the terms of the court proceedings;

11) inadmissibility of abuse of procedural rights;

12) reimbursement of legal costs to the party in favor of which the court decision was taken [18].

In accordance with the provisions of Article 11 of the Commercial Procedure Code, the economic court is guided by the rule of law when considering a case; the court shall consider cases in accordance with the Constitution of Ukraine, the laws of Ukraine, international treaties, the consent for which has been given by the Verkhovna Rada of Ukraine; the court applies the Convention for the Protection of Human Rights and Fundamental Freedoms of 1950 and its protocols in cases, consent to be made binding by the Verkhovna Rada of Ukraine, and the case law of the European Court of Human Rights as a source of law.

Thus, the new version of the CPC introduces the consideration of economic cases by the courts on the principles of justice and the rule of law, without disclosing the legal content of these categories, which leads to the formation of different approaches in the field of law enforcement and does not promote the unity of case law.

Comparison of Section III of Article 2 of the Commercial Procedure Code with the previous version of this Code gives grounds to conclude that the novelty of the current Commercial Procedure Code is to introduce ratability, reasonableness of terms of court proceedings, inadmissibility of abuse of procedural rights into the principles of economic litigation, which were not applied in commercial litigation before its reform in 2016, that testifies to Ukraine's fulfillment of its international obligations and implementation of international legal principles of judicial protection of individual rights in national procedural legislation.

The CPC operates the legal category of "litigation", at the same time, the Constitution of Ukraine, in addition to this category, further introduces the concept of "justice" [3, art.art. 124, 129], that necessitates a study of their relationship.

Although the theoretical development of the main provisions of commercial procedural law is reflected in the writings of domestic business scientists, the legal nature of such categories as justice, the rule of law, ratability, the binding nature of court decisions, the reasonableness 
of the terms of the court proceedings, the inadmissibility of abuse of procedural rights in the context of the administration of justice is not revealed, which makes the relevance of their scientific research.

\subsection{Jurisdiction}

Article 129 of the Constitution of Ukraine establishes the following principles of jurisdiction: 1) equality of all parties to the lawsuit before the law and the court; 2) ensuring the provenance of guilt;3) the parties' competitiveness and freedom to present their evidence to the court and to prove their conviction before the court;4) support of public prosecution in court by the prosecutor; 5) providing the accused with the right to defense; 6) publicity of the trial and its full fixation by technical means;7) reasonable time for trial;8) ensuring the right to appeal the case and in the cases specified by law - to appeal against the court decision; 9) binding nature of court decisions.

At the same time, Article 2 of the CPC defines economic litigation as a court hearing of economic cases.

The analysis of the provisions of Article 129 of the Constitution of Ukraine and Article 2 of the Commercial Procedure Code in their interconnection gives grounds to conclude that economic proceedings should be understood exclusively as a procedural activity of economic courts, related to the handling of business cases (disputes); the purpose of economic litigation is to protect the rights and legitimate interests of individuals and legal entities, as well as the state [13, p. 53].

\subsection{Jurisdiction}

Article 124 of the Constitution of Ukraine states that only the courts administer the jurisdiction.

In his study of jurisdiction as a legal category, S.P. Pogrebniak proposed to consider the jurisdiction as a procedure that makes it possible to combine law with justice [8, p. 14]. According to Aristotle (Ethics V, 7, “... Going to court means appealing to justice because a judge wants to be a personification of justice. In addition, people seek an impartial judge and sometimes call judges "mediators" to determine that having reached a fair decision, they will begin to stay in the middle "[15, p. 414].

Thus, in the philosophy of the law of justice, it is primarily identified with the adoption of a just decision by the courts.

This allows us to conclude that not every case is a jurisdiction, since not every court decision meets the criteria of justice, even if it is adopted in strict accordance with procedural and substantive law [13, p. 54].

Therefore, the concept of "justice" is much broader than the concept of "jurisdiction", because, if the administration of justice reflects exclusively the procedural activity of the court in accordance with the procedural rules laid down by procedural law, then the jurisdiction is the process of dispute resolution and adjudication, which must comply with the principles of justice and ensure effective protection and / or restoration of the violated rights and legitimate interests of individuals, legal entities and the state.

The administration of justice requires judges to adhere to substantive and procedural law, while assessing those rules for compliance with the principles of justice and the rule of law, which, in some cases, provides for the possibility of a judge's departure from the 
application of the rules of the law in force, if this leads to the adoption of a formally legal but unfair court decision and does not provide effective protection and / or restoration of the violated rights and legitimate interests of the victim.

Apparently, it was from such positions that the developers of the amendments to the Constitution of Ukraine, adopted by the Law of 02.06.2016 No. 1401-VIII, started, which excluded from the previous version of Article 129 of the Constitution of Ukraine such a basis of jurisdiction as lawfulness.

\subsection{Justice}

Justice is primarily a philosophical category. In the typology of "justice" category, R.A. Dzhabrailov distinguishes "equitable justice", which aims to maximize the equality of rights and opportunities of social actors, as well as "retaliatory justice", which extends to the sphere of punishments for offenses and is a guarantee of bringing to justice [3, p. 75].

Since ancient times, justice has been embodied with the main idea of law as an institutional mechanism for the implementation and practical administration of justice, which is subject to concretization every time [14, p. 366].

In jurisprudence, they distinguish between objective (institutional) and subjective (personal) justice, as well as substantive and procedural justice.

Objective justice is the implementation of basic ideas of justice in certain social institutions (economy, education, families and etc.); subjective justice is the integrity of a person who voluntarily fulfills the requirements of institutional justice; material justice is the incorporation of ideas of justice into legislation that regulates specific legal relationships, and procedural justice - the implementation of the rules of law of ideas that ensure the proper and impartial consideration of the dispute by the court, as well as the equality of all participants in the trial before the law and the court [6, p. 41; 20, p. 79-84].

An example of the implementation of objective justice embodied in substantive law is the enshrining in the Commercial Code of Ukraine of the provisions that management should be carried out on the basis of ensuring economic diversity and equal protection of all economic entities by the state; freedom of business within the limits set by law; free movement of capital, goods and services within Ukraine; restriction of state regulation of economic processes due to the need to ensure the social orientation of the economy, fair competition in business, environmental protection of the population, protection of consumer rights and safety of the society and the state; protection of the national producer; prohibition of unlawful interference of public authorities and local selfgovernment bodies, their officials in economic relations [19, Art. 6].

An example of procedural justice is the norms of Article 129 of the Constitution of Ukraine and Para 3 of Article 2 of the Commercial Procedure Code, which guarantees the equality of all parties to the lawsuit before the law and the court.

As Ulpianus stated: «Justitia est constans et perpetua voluntas jus suum cuique tribuendi» Justice is unwavering and permanent desire to give to everyone everything, which is owned by him) [9, p. 86-88].

As it is stated by N.V.Ivanyuta, the urgent need for the progressive implementation of the principle of justice in national procedural fields is due to radical changes in Ukraine, which has led to a strengthening of the international legal framework in the field of 
justice. The latter are primarily the Universal Declaration of Human Rights, The International Covenant on Civil and Political Rights, The Convention for the Protection of Human Rights and Fundamental Freedoms, The Recommendation of the Committee of the Council of Ministers of Europe, The Hague Convention on International Access to Justice, The American Convention on Human Rights, The CIS Convention on Human Rights and Fundamental Freedoms, The Charter of Fundamental Rights of the European Union [7, p. 59].

In the light of the approaches discussed above for defining the category of justice, in the context of the administration of justice, the effective restoration and / or protection of the violated (unrecognized or contested) rights, justice should be considered freedoms and interests of a person, what happens in the process of resolving the dispute by an impartial court, based on the equality of all participants in the process and providing them with equal opportunities in the exercise of their procedural rights [13, p. 55].

\subsection{Rule of Law}

Law is a universal regulator of social relations through which litigation is resolved. Today, there are two fundamental concepts of law in the world: the concept of positive law (state-centrist concept) and the concept of natural law (human-centrist concept). Proponents of the concept of positive law identify the law solely with state-mandated legislation. This approach to the definition of law completely ignores the moral aspects of the relations of the subjects of law and considers the person, first of all, as an object of law, the behavior of which is subject to regulation by law without regard to the position of the person himself. The concept of positive law does not recognize a judge's right to take a creative approach to resolving a dispute based on the particular circumstances of the case.

The concept of positive law makes absolute the dogmatic and formal-logical methods of law, which is derived from the theory of Hans Kelsen (1881 - 1973), which is described in detail in the paper entitled "Pure Theory of Law". As a starting point, Hans Kelsen applies the neo-Kantian theory of law and concludes that law is the normative ordering of human behavior by means of a legal norm, which is objectively valid only when the human behavior it regulates actually responds to it - at least to some extent [10, p. 14, 21].

A well-known legal positivist of the XIX century, John Austin believed that the basis of law was power and will; law is a command of a sovereign, a man commanded by other people, and who usually does not obey the orders of others; the reason for the habit of obeying is for the most part the power that threatens sanctions for disobedience, not the moral authority of the sovereign [1, p. 13].

Thus, supporters of the concept of legal positivism associate law with the will of the ruling elite and do not relate to morality.

However, as M.I.Kozyuba points out, positive law works only when legislation meets the needs of citizens and society as a whole, with accumulated legal values; when it is timely updated and is not formally-dogmatically applied. Identifying it with law, as is still the case in the domestic theory of law, especially in the field of sciences and in legal practice, is incorrect [5, p. 36].

The concept of natural law began to be developed in ancient Greece and ancient Rome 
by such philosophers as Democritus, Socrates, Plato, Aristotle, Cicero and others.

The fundamental idea of the natural-law concept is that the right comes from the person himself, and is not granted by the state, and is aimed at providing the person with a decent life. Unlike the theory of positive law, the natural-law type of legal thinking treats a person primarily as a creator of law, that is, as a subject, not as an object of law. Natural law is based on the principles of morality, justice and efficiency, which constitute the philosophical and axiological basis of its formation, and not on formal dogmas and rules [12, p. 86-95].

If the content of the rule of law corresponds to the motivating factor of the person, we can speak about the morality of the rule of law. However, the morality of the rule of law is an appraisal category and depends on the views prevailing in the society over a period. At his time, the famous German philosopher Eduard Spranger (1882 - 1963) stated: "Ranking of values, carried out by collective morality for typical situations, is based on judgments, which must be exercised by a particular individual consciousness, because the society judges only in the form of judgments of its ranks and through them ... Accordingly, every new moral evaluation must ever be individually defended, and the arena of struggle becomes the conscience of an individual as a member of the society. Collective assessments, such as requirements contained in the mind, are involved in this struggle. In this sense, the value judgments of collective morality merge with social and ethical experience, manifestations of will and experience of the norms of many generations "[17, p. 306, 328].

Research on various aspects of the morality of law was conducted in the second half of the twentieth century by a professor at Harvard Law School, Lon Fuller, who viewed morality as a desire for perfection and personal fulfillment. In turn, he referred the clarity of the laws and their compliance with the criteria of justice; mandatory promulgation of laws; the impossibility of retroactive effect in time of laws that impair the legal status of a person to the elements of the morality of law [4].

The European Court of Human Rights also urges a clear wording of the legislative provision (hereinafter - the ECHR), by which in paragraph 47 of the case Koretskyi v. Ukraine was stated: The law must be accessible to the individual and formulated with sufficient clarity to enable him, if necessary, to foresee, with the assistance of qualified counsel, within reasonable circumstances, on the basis of the circumstances of the case, the consequences which the said action may cause. In order for a provision of national law to meet these requirements, it must guarantee a remedy against arbitrary interference by public authorities with the rights guaranteed by the Convention. In matters relating to fundamental rights, the granting of legal discretion to the executive authorities in the form of unlimited powers would be incompatible with the rule of law, one of the fundamental principles of a democratic society guaranteed by the Convention. Accordingly, the law must clearly define the limits of such discretion and the manner in which it is exercised. The degree of clarity required by national legislation - which, of course, cannot provide for all possible cases, - depends largely on the particular issue under consideration, on the sphere governed by this legislation, and on the number and status of the persons concerned. "

In order for a certain norm to be considered moral it is not necessary that such a norm is considered moral by all members of the society - this requires recognition of the 
morality of the norm in that layer of society that determines the general direction of its development, as well as support for the majority of the law-abiding population of the country, which is also a manifestation of democracy in the process of forming and adopting norms of law [12, p. 89].

It should be noted that the convergence of legal norms and collective morality is the ideal state of a democratic society. Most countries of the world are faced with a situation where, through state coercion, even those legal norms that do not conform to the social morality of society are implemented. In such a case, the rule of law may not be accepted by the society.

According to the institutional theory of law, represented by Friedrich Carl von Savigny (1779 - 1861), the law has no existence in itself; its essence is the life of people, viewed from a certain side $[16$, p. 8,30$]$. According to this theory, the law of the state cannot be separated from the society; it always reflects its mentality, culture, customs, and is a product of the common efforts of the entire people and their historical experience.

Main provisions of the concept of natural law enshrined in the Convention for the Protection of Human Rights and Fundamental Freedoms were reflected in the Constitution of Ukraine, in particular: recognition in Ukraine of the highest social value of a person, his life and health, honor and dignity, integrity and security; recognizing all people as equal in their dignity and rights; recognition of the inalienability, inviolability and inexhaustibility of rights and freedoms of a man and a citizen; recognition for each person of an inalienable right to life, respect for his or her dignity; guaranteeing each person the right to personal and inviolable housing; guaranteeing everyone the secret of correspondence and prohibition of interference with privacy and family life; guaranteeing everyone the right to freedom of thought, outlook and religion, the right to freedom of association with political parties and public organizations to exercise and protect their rights and freedoms and to satisfy political, economic, social, cultural and other interests [2; 18, Art. 3, 21, 22, 27-32, 34-36].

Obviously, in the current economic and social development of the state, natural law provisions are not able to regulate fully the entire spectrum of existing legal relationships, in particular, relations arising in the field of economic competition, tax, financial relations, etc. The previously mentioned imposes on the state the obligation to regulate them by means of special legislation pertaining to the system of positive law. However, when adopting such acts, the state must ensure that they comply with the basic criteria of natural law, in particular, morality, justice and efficiency.

Based on the analysis, the main elements of the rule of law include:

1) observance of fundamental human rights enshrined in the Constitution of Ukraine and international instruments that are part of the national legislation of Ukraine;

2) compliance of national legislative acts with the principle of legal certainty and fundamental rights enshrined in the Constitution of Ukraine and international legal acts;

3) guaranteeing everyone the right to an independent, impartial and fair trial, the actual enforcement of court decisions, without which judicial protection is illusory.

\subsection{The pro rata principle of economic litigation}

This principle is revealed in Article 15 of the Commercial Procedure Code as a need to be taken into consideration by the court the task of economic litigation; ensuring 
a reasonable balance between private and public interests; peculiarities of the subject of dispute; the cost of the claim; the complexity of the case and the importance of the case to the parties; the time it takes to perform certain actions; the amount of the costs of the proceedings.

In this list of elements of the pro rata principle, the greatest difficulty for practical application is to strike a balance between private and public interests, since the legislator does not propose ways of addressing this issue.

At the same time, in paragraph 39 of the ECHR judgment in the Seryavin v. Ukraine case, the pro rata principle is disclosed as the need for the courts to strike a fair balance between general interests of the society and requirements for the protection of the fundamental freedoms of a particular person. In doing so, the ECHR states that the issue of whether such a fair balance was ensured becomes relevant only after it is established that the relevant state intervention met the requirement of lawfulness and was not arbitrary (see decision in the case Beyeler v. Italy).

\subsection{Binding nature of court decision}

Binding nature of court decision is a guarantee of the actual restoration of a person's violated rights. This principle envisages not only the obligation of the person subject to the decision, as soon as possible to abide this decision, but also the obligation of the state to enforce the decision in the event of evasion of the debtor (legal or natural person) from its execution; another aspect of this principle is the legislative guarantee of the impossibility of reversing a court decision that has become final.

This conclusion follows from the ECHR's decisions in cases Haruk v. Ukraine and Alpatov and Others v. Ukraine, in which it finds a violation of Article 6 \& 1 , Article 13 of the European Convention for the Protection of Human Rights and Fundamental Freedoms, prolonged failure to comply with decisions taken in favor of the applicants, and the applicants therefore lacked an effective national remedy to obtain compensation for the damage caused by such non-compliance.

In addition, paragraph 40 of the ECHR judgment in Ponomarev v. Ukraine case states that one of the fundamental aspects of the rule of law is the principle of legal certainty, which presupposes respect for the principle of res judicata - the principle of finality of court decisions. This principle emphasizes that neither party has the right to require a final and binding decision of the court to be reviewed simply because it seeks a new hearing and a new decision. The powers of the higher judicial authorities with respect to review should be exercised to remedy judicial errors and deficiencies in the judiciary, but not to reopen judicial proceedings. Revision should not in fact substitute for appeal, and the mere existence of two points of view on one subject does not warrant a new review. Exceptions to this principle may take place only on the ground of circumstances of an important and compelling nature.

It should be noted that the enforcement of the judgment is influenced by the subjective attitude of the debtor to this decision, which depends on how complete and valid the judgment is, as well as the completeness and quality of the court's reasoning in the judgment, enabling the individual to assess whether he or she has been heard by the court.

Thus, paragraph 58 of the ECHR judgment in Seryavin et al. v. Ukraine case emphasizes 
that the decisions of the courts and other dispute resolution bodies must properly state the grounds on which they are based; although Article $6 \$ 1$ of the Convention obliges the courts to substantiate their decisions, it cannot be interpreted as requiring a detailed response to each argument; the extent to which a court must fulfill its obligation to justify a decision may vary depending on the nature of the decision to show the parties that they have been heard. Only if a valid decision is rendered, public control of justice can be ensured (see the judgment in Hirvisaari v. Finland).

\subsection{Reasonableness of the terms of trial}

This issue is not revealed in The Commercial Procedure Code. However, it is possible to conclude from the provisions of Articles 195, 248 of this Code that the legislator has determined a reasonable term of consideration of economic cases 60 days, which is counted from the day of opening of the case and can be continued by the court. Imperative determination of the term of consideration of cases by an economic court is unjustified, since this approach does not take into consideration many factors that can objectively affect the timing of cases; they are not dependent on the court action. Unconditional adherence to the law by the court, which sets the terms of consideration of business cases, may violate the rights of participants in controversial relationships, the impossibility of collecting all the necessary evidence and, as a consequence, the adoption of an unjust decision.

In this context, ECHR case-law should be followed in determining the issue of reasonableness, which, in paragraph 66 of the judgment in Smirnova v. Ukraine case, defined the legal position that the reasonableness of the length of court proceedings should be assessed in the light of the circumstances of the case and in the light of the following criteria: the complexity of the case, the conduct of the applicant and the relevant authorities, and the subject-matter of the dispute (see, inter alia, Frydlender v. France, N 30979/96, \& 43, ECHR 2000-VII).

\subsection{Inadmissibility of the abuse of procedural rights}

In order to prevent abuse by the participants of the case of their procedural rights, the current Commercial Procedure Code contains Chapter 9, which determines measures of procedural coercion, that is, procedural actions taken by an economic court to induce persons to comply with the rules established in court, the proper discharge of procedural obligations, the cessation of abuse of rights and the prevention of unlawful obstruction of justice.

Article 132 of the Commercial Procedure Code refers warning, removal from the courtroom, temporary seizure of evidence for court investigation, fine to the types of measures of procedural coercion.

Removal from the courtroom shall be applied only if the person fails to comply with the orders of the judge - after the application of the warning.

Temporary seizure of evidence shall be effected based on a reasoned court order, in the event of failure to provide valid, written, material or electronic evidence required by the court. The decision on the temporary withdrawal of evidence is an executive document and is subject to immediate execution in accordance with the procedure established by the Law of Ukraine "On Enforcement Proceedings". 
The fine, as a measure of procedural influence, may be applied on the basis of a court order in the case of evasion of a party to the case from performing actions imposed by the court; abuse of procedural rights with the purpose of obstruction of justice; failure to notify the court of the inability to produce the evidence required by it or the failure to submit evidence to the court without good reason; failure to comply with a court order securing a claim or evidence, failing to provide a copy of a statement of claim, etc.

The court's decision to recover the fine is an executive document, and the amount of the fine collected by the court is credited to the State Budget of Ukraine.

\section{Proposals for the Improvement of the Economic Procedural Legislation of Ukraine}

The article proves that the recent legislative changes approved by the Verkhovna Rada of Ukraine within the framework of the judicial reform, ensured the implementation of modern international legal principles of judicial protection of the rights of the participants of economic relations in the national legislation which is a reliable guarantee for the sustainable development of the state in the years to come.

However, the study of the provisions of the current Commercial Procedure Code, which determines the jurisdiction of commercial courts and establishes the procedure for the implementation of commercial litigation, indicates that it has separate rules, enabling dishonest legal entities to delay dispute resolution in commercial courts by abusing their procedural rights, and complicate the access to court and the resolution of certain categories of business cases, which in the aggregate leads to a decrease in the effectiveness of the judicial protection of the rights of participants in economic relations and, at the same time, indicates that there is a need to improve the current economic procedural legislation of Ukraine, taking into consideration requirements of the sustainable development of Ukraine.

Thus, under Article 16 of the Commercial Procedure Code, the parties to the case are entitled to use legal assistance provided solely by a lawyer (professional legal assistance), except in cases prescribed by law.

Article 58 of the CPC stipulates that a lawyer or legal representative may be represented in a commercial court. When considering cases in minor disputes (minor cases), an adult may be represented by a person that has a civil procedural capacity.

The authority of a non-lawyer representative may be verified by the power of attorney of a natural or legal person.

Pursuant to Section V of Article 12 of the CPC, the following cases are considered insignificant:

1) in which the cost of the claim does not exceed one hundred subsistence levels for able-bodied persons;

2) cases of insignificant complexity, recognized by the court as insignificant, except for cases which are subject to review only under the rules of general claim proceedings, and cases where the cost of a claim exceeds five hundred the minimum subsistence level for able-bodied persons.

At the same time, under Article 247 (4) of the Commercial Procedure Code, the following may not be regarded as minor cases: 
1) bankruptcy cases;

2) cases on applications for approval of the debtor's rehabilitation plans prior to opening bankruptcy proceedings;

3) disputes arising out of corporate relations and disputes concerning transactions relating corporate rights (shares);

4) disputes concerning the protection of intellectual property rights, except for cases concerning the recovery of a sum of money which does not exceed one hundred minimum subsistence amounts for able-bodied persons;

5) disputes arising from relations related to the protection of economic competition, restriction of monopoly in economic activity, protection against unfair competition;

6) disputes between the legal entity and its official (including the official whose termination is terminated) about compensation of the damage caused by such official to the legal entity by his actions (inaction);

7) disputes concerning the privatization of state or communal property;

8) cases in which the cost of the claim exceeds five hundred minimum subsistence levels for able-bodied persons.

Thus, in a commercial court, the representative of a party to the case, which is not insignificant, under the current CPC can only be a lawyer; one of the main criteria for classifying cases in the category of insignificance is the cost of the claim, which can be argued, since the cost of the claim does not in any way affect the complexity of the case, but may only serve as an additional criterion for the relevance of the case to the participant.

Since Ukraine's independence, business entities, that have active economic activities, have established in their structure legal services or have in-house legal advisers specializing in the application of economic legislation governing the activity of these entities, and therefore have considerable professional experience and practical skills, which enable them to protect at an appropriate level the rights of these economic entities in the commercial courts. However, changes introduced in the CPC regarding the representation in the courts of the rights of economic entities in matters of minor importance exclusively by lawyers, who are usually engaged in the common law practice and are not familiar with the specifics of the economic legislation governing particular areas of business, are inappropriate, and generally do not contribute to improving the protection of the rights of such entities.

In addition, having a legal service within a business organization, an entity is now forced to seek a lawyer in the court who has experience in applying the laws governing activity in certain areas of business, and to incur additional costs for the payment of fees, which adversely affect the economic activity of such entity.

In such circumstances, it is appropriate to amend Article 58 of the CPC, which will allow entities that have a non-lawyer legal counsel status in the commercial courts to represent the interests of those entities.

The novelty of the current CPC is the introduction into the circle of other participants of the case of an expert on law, which may be a person who has a scientific degree and is a recognized expert in the field of law. The legal expert is allowed to participate in the case based on a court order (Article 70).

For the purposes of Article 108 of the Commercial Procedure Code, an expert in the 
field of law has the right to give a judgment on:

1) application of the analogy of legislation, the analogy of law;

2) the content of the rules of foreign law in accordance with their official or generally accepted interpretation, practice of application, doctrine in the respective foreign country.

An expert's opinion in the field of law cannot contain an assessment of the evidence, an indication of the reliability or inaccuracy of one or the other evidence, of the advantages of one evidence over the other, of what decision should be taken as a result of the case.

The analysis of the content of the above articles shows that a law expert cannot give a court a conclusion on the content and interpretation of the rules of the national law, which greatly limits the possibility of using in the Commercial Court the scientific potential of domestic scientific schools and individual scientists who have the recognized authority not only in Ukraine but in the world.

Therefore, in Article 108, Section II of the Commercial Procedure Code, after the phrase "the content of foreign norms" should be supplemented with the phrase "and national", that will give the Commercial Courts of Ukraine the opportunity to use the opinions of experts on the content and interpretation of not only the rules of international law, but also the rules of national law, which will help to improve the quality of commercial litigation.

For the first time in the history of commercial litigation, the Institute of Criminal Proceedings was introduced by the current Commercial Procedure Code, which provides for the possibility of issuing a court order, which is a type of court decision, according to the requirements for the collection of monetary debt under the agreement, concluded in writing (including electronic) form, if the amount of the claim does not exceed one hundred minimum subsistence amounts for able-bodied persons (Article 148).

The peculiarity of criminal proceedings is the speed of resolution of the case, because the court reviews the claimant's application for a court order within five days after its receipt, without notifying the applicant and the debtor and holding a court hearing.

Introduction of the institute of criminal proceedings helps to reduce the burden on commercial courts and reduce the timeframe for consideration of insignificant cases of debt collection under a contract concluded in writing (including electronic) form, that is, cases in which the claimant's claims are supported by conclusive evidence.

However, under Section III of Article 158 of the Commercial Procedure Code, in the event of the debtor submitting an application for revocation of a court order and there are no grounds for returning an application for revocation of a court order, the judge shall, no later than two days after its submission, issue a decree revoking the court order explaining to the applicant (claimant) his right to apply to the court with the same requirements in the order of summary action.

The basis for the return of the debtor's application for revocation of the court order is the filing of an improperly filed application by the court, which in form and content does not meet the requirements of Section III of Article 157 of the Commercial Procedure Code.

Thus, Articles 157, 158 of the CPC set out the rule of unconditional cancellation of a court order issued by a court, if the debtor submits an application within the terms and conditions established by this Code, regardless of whether the debtor disputes the 
amount of debt or the legality of the court order itself or not.

This situation actually negates the benefits of criminal proceedings, gives a dishonest debtor the opportunity to abuse his procedural rights and to demand the revocation of a court order, even if such an order fully complies with the requirements of fairness and legality, supported by the appropriate and admissible evidence.

This justifies the need to set out Section III of Article 158 of the Commercial Procedure Code in another version, which provides for the possibility of revoking a court order only if the debtor proves its incorrectness or illegality.

Section III of Article 195 of the Commercial Procedure Code establishes that the court is not entitled to suspend the proceedings at the stage of its consideration on the merits on the grounds provided for in paragraph 5 of Section I of Article 227 (the objective impossibility of considering a case before the resolution of another case, which is considered in the procedure of constitutional proceedings, administrative, civil, economic or criminal proceedings - until a court decision in another case becomes enforceable) and paragraph 2 of Section I of Article 228 of this Code (appointment by a court expertise); such actions can only be taken by the court during a preparatory hearing.

This provision cannot be considered as justified and conducive to improving the quality of justice, whereas the need for a forensic examination may also arise at the merits of the case, after examining the evidence in the case, which (given the complexity of the case) could not be identified in the preparatory meeting, which is quite common in practice. The existence of another case, considered in the course of constitutional proceedings, administrative, civil, economic or criminal proceedings and which directly influences the consideration of an economic case, may also be made known to the court or the participants of the case after the preparatory session, or such a case may arise after a preparatory meeting.

In fact, the norm of Section III of Article 195 of the CPC obliges a court to conduct a review of an economic case in substance where such consideration is temporarily impossible for objective reasons that affect the proper resolution of the economic dispute by the court.

Therefore, it seems correct to exclude part three of Article 195 of the CPC.

Pursuant to paragraph 5 of Section I of Article 226 of the Commercial Procedure Code, the Commercial Court leaves the claim without consideration of the claimant's application, which was filed only before the merits of the case.

That is, if the court has already commenced the merits of the case, the claimant is deprived of the right to file such an application, for example, if, after clarifying the particular circumstances of the case, there is a need to change the basis and / or subject matter of the claim, which entails the inappropriateness of further maintaining the claim and spending both its own efforts and the capacity of the court to resolve the particular dispute to which the claimant has lost interest.

In addition, the above-mentioned norm of the CPC contradicts one of the basic principles of economic litigation - the disposition principle, which enshrines the claimant's right, at his own discretion, to dispose of his rights in relation to the subjectmatter of the dispute, without limiting that right to certain stages of litigation (Article 14). 
On this basis, the phrase "prior to the trial of the merits" should be deleted from paragraph 5 of Section I of Article 226 of the CPC.

The anachronism of the Soviet judicial system should be considered as the provisions of Section I of Article 220 of the Commercial Procedure Code (mystery of the meeting room), which stipulates that during the decision making no one has the right to be in the conference room except the court hearing the case.

The analysis of the provisions of this part gives reason to believe that after leaving the court to the conference room, the court is not entitled to leave this room until it decides on the case. However, in today's context, characterized by the complexity of business relationships and the law that governs them, compliance with these regulations is virtually impossible, given that individual judgments are made over a long period of time, which can count for days or even weeks. At this time, the judge adjudicating the case is studying the current law, case law, using the potential of the Internet; he or she can consult with colleagues who have experience in resolving similar litigation; eats; walks home for rest, which formally forms the composition of the breach of the secret room in the sense that it is defined in the article.

However, the physical abandonment by a judge of his office while working on a court decision in a case does not indicate a breach of the secrecy of the court decision, if the judge did not inform the other persons that he was going to make the decision and the reasons for its decision by the time of the public announcement of the court decision.

The existence of Section I of Article 220 of the Commercial Procedure Code allows any party to the case to request the annulment of a court decision that has been taken in a period that exceeds the judge's working day,- on grounds of breach of the secrecy of the conference room, since it is obvious that all this time the judge was physically unable to stay in the conference room because of the need to meet his physiological needs for food, rest, etc.

Therefore, the provision of Section I of Article 220 of the CPC is subject to exclusion.

Section I of Article 310 of the Commercial Procedure Code defines the grounds for the total or partial annulment of lower court decisions and the referral of a case for reconsideration or for the continuation of proceedings if:

1) the case was considered and resolved by a non-statutory court;

2) the judge involved in the decision was dismissed, and the court of cassation recognized the grounds for his dismissal justified;

3) the court decision is not signed by any of the judges or signed by the other judges mentioned in the court decision;

4) the court decision was made by judges who were not part of the panel hearing the case;

5) the case is considered in the absence of any of the parties to the case, who have not been duly informed of the date, time and place of the court hearing, if such a participant of the case substantiates his cassation appeal with such grounds;

6) the court decision was made in violation of the rules of the instance or territorial jurisdiction;

7) the court considered the case, which was subject to consideration in accordance with the rules of the general lawsuit, in the order of summary action;

8) the court ruled on the rights, interests and (or) responsibilities of the persons not 
involved in the case.

It should be noted that the above grounds can be established and eliminated during the appeal review of the case. The granting of the Supreme Court the right to refer the case back to trial creates both the preconditions for the abuse of this right by the judges of the court of cassation, for the purpose of evading the adoption of a court decision, in the event of the total or partial revocation of court decisions by courts of lower jurisdiction, and to an unjustified increase in the length of the trial, which impairs the effectiveness of the protection of the rights of economic entities.

The above points to the need to bring the provisions of Article 310 of the Commercial Procedure Code into line with the international principles of judicial proceedings by excluding part one of this article.

The established by CPC procedure for reviewing court decisions in newly discovered or exceptional circumstances creates significant problems for the court reviewing such a decision when considering the application of the party to the case, which negatively affects the quality of the review.

Thus, in accordance with Sections II, III of Article 320 of the Commercial Procedure Code, the grounds for reviewing a judgment on newly discovered circumstances are:

1) material circumstances of the case that were not established by the court and were not and could not be known to the person applying for the case at the time of the case;

2) established by a verdict or decision to close a criminal proceeding and release a person from criminal responsibility that has come into force, the fact of giving a knowingly incorrect expert opinion, knowingly false witness testimony, knowingly incorrect translation, falsity of written, material or electronic evidence that led to an unlawful decision in the case;

3) revocation of the court decision, which became the basis for the judgment to be reviewed.

Grounds for reviewing court decisions in exceptional circumstances are:

1) unconstitutionality (constitutionality) of a law established by the Constitution of Ukraine, other legal act or their separate provision applied (not applied) by a court in the decision of a case, if the court decision has not yet been enforced;

2) establishment by an international court of jurisdiction recognized by Ukraine of the violation from the side of Ukraine of international obligations by a court in the settlement of this case;

3) imposition of a verdict by a court which has entered into force, the guilt of a judge for committing a crime which resulted in a court decision.

Section III of Article 325 of the Commercial Procedure Code states that, as a result of the review of a judgment in newly discovered or exceptional circumstances, the court may:

1) refuse to grant an application for review of a judgment on newly discovered or exceptional circumstances and leave the relevant court decision in force;

2) satisfy the application for review of the court decision in newly discovered or exceptional circumstances, cancel the corresponding court decision and make a new decision or change the decision;

3) set aside the judgment and close the case or dismiss the case.

First of all, it should be noted that the main task of the court in reviewing the application 
for review of the judgment in newly discovered or exceptional circumstances is to establish the existence of such circumstances at the time of the case and the court decision, which is the basis for rescission of the court decision and re-examination of the case in the light of newly discovered or exceptional circumstances. However, the rule laid down in paragraph 2 of Section III of Article 325 of the Commercial Procedure Code imposes on the court the obligation to establish the existence of newly discovered or exceptional circumstances affecting the decision taken, not only to annul such decision but also to render a new court decision immediately.

Such a procedure presupposes that if, in the course of reviewing an application for review of a decision on new or exceptional circumstances, the court concludes that they exist, then the court must concurrently review the case on the merits, providing for a rehearing of all participants in the case, examination of written, electronic and physical evidence, interrogation of witnesses and forensic examination. Thereby, the court discloses to the participants of the case its intention to satisfy the application for review of the decision on newly discovered or exceptional circumstances while in the process of considering the application for review of the court decision on newly discovered or exceptional circumstances - pending the adoption of the relevant court decision, which gives the case party a reasonable basis to request the judge's withdrawal, due to the revealed prejudice during the consideration of the application.

On this basis, the procedure for reviewing court decisions in newly discovered or exceptional circumstances is subject to change - and if the court concludes that at the time of the case the newly discovered or exceptional circumstances affecting the decision have been taken, the court must order the application, revoke the judgment and order a retrial.

To this end, paragraph 2 of Section III of Article 325 shall be read as follows: "satisfy the application for review of the judgment in newly discovered or exceptional circumstances, cancel the relevant court decision and order a retrial."

The CPC contains Section VI, which defines the procedure for exercising judicial control over the enforcement of judgments adopted in commercial litigation, which fully complies with international standards of justice.

According to Section II of Article 343 of the Commercial Procedure Code, in the determination of the merits of a complaint, the court finds the contested decisions, actions or omissions unlawful and obliges the State Enforcement Officer or other official of the Bailiff, Private Bailiff to remedy the violation (to renew the infringed right of the applicant).

Thus, provisions of this article confer on the economic court the right to make a judgment exclusively of a binding nature, which imposes on the state bailiff or other official of a body of state executive service, a private bailiff the obligation to eliminate the violation established by the court and to renew the infringed right of the applicant, it does not give the economic court the right to independently annul the decisions of the listed persons, which is declared illegal, which reduces the effectiveness of judicial control over the enforcement of court decisions, whereas, unlike a court decision declaring a public or private enforcement agent's decision unlawful and its cancellation having direct effect, a binding decision provides for a decision of a higher state official to be overturned by a senior executive body, which was declared illegal by the court; the 
Law of Ukraine "On Enforcement Proceedings" does not at all determine who should annul the decision of a private executor, in the case of its recognition as an illegal commercial court, which is a significant disadvantage of this Law and complicates the real protection of the participants in enforcement proceedings.

For the reasons stated above, it is advisable to set out the Section II of Article 343 of the CPC in the following wording: "If the appeal is well founded, the court finds the contested decisions, actions or omissions unlawful and annul the contested decision and / or oblige the bailiff or other official of the public enforcement agency, the private bailiff to remedy the infringement (renew the infringed right of the applicant)."

The biggest institutional problem in Ukraine's procedural law right now is compliance with the principle of legitimacy (legality) of the court activity, which is of particular importance, whereas any judgment is not in conformity with the requirements of Article 6 of the Convention if it is taken by a court established in breach of the national law.

From this point of view, the order of formation and operation of the Supreme Court is of particular concern.

The problem is that the draft Law No. 1401-VIII on Amendments to the Constitution of Ukraine, which was approved by the Constitutional Court of Ukraine, did not refer to the Supreme Court of Ukraine being liquidated but renamed; the Constitution of Ukraine itself does not contain rules that provide for the possibility of liquidation of the Supreme Court of Ukraine, which has the constitutional status of the highest judicial body, in connection with which it can not be liquidated by another body of state power the Verkhovna Rada of Ukraine, since in such a case the principles of division of state power established by the Constitution into legislative, executive and judicial are violated and preconditions for usurpation of power by the body of legislative power of Ukraine are created.

Liquidation of the Supreme Court of Ukraine and creation on its basis of the new highest court in the judicial system of Ukraine - the Supreme Court, actually took place on the basis of the Final and Transitional Provisions of the Law of Ukraine "On Judiciary and Status of Judges" No. 1402-VIII, which casts doubt on the correctness of this procedure and its constitutionality, since, based on a hierarchy of legislative acts, ordinary law cannot change the legal basis established by the Constitution of Ukraine, which is the Basic Law of the state.

There are also ambiguous questions about the expediency of introducing into the structure of the Supreme Court four courts of cassation (criminal, civil, economic, administrative) that specialize in the consideration of criminal, civil, economic and administrative cases and act as courts of cassation, however, not as a separate court, but in the Supreme Court, which also has the status of a court of cassation and acts in the Grand Chamber, consisting of 21 judges, at the same time, it has the power to review the judgments of the cassation courts of the Supreme Court adopted by them as courts of cassation.

This gives reason to consider the Supreme Court a court of double cassation, which has no analogues in the world. At the same time, it should be noted that double cassation is not envisaged by Article 129 of the Constitution of Ukraine, which defines the basic principles of justice in Ukraine. 


\section{Conclusions}

The conducted research gives grounds to conclude that the principles of commercial litigation, enshrined in the Commercial Procedure Code, are based on the international legal principles of protection of individual rights, which allows ensuring in Ukraine effective judicial protection of the rights of all economic entities, regardless of ownership.

The analysis of the CPC provisions revealed certain norms that reduce the effectiveness of the judicial protection of the rights of participants in economic relations, and suggest ways to remedy the shortcomings.

There were reasonable doubts as to the proper provision by the State of Ukraine of the criterion of legitimacy (legality) of the Supreme Court's activity, the final resolution of which is possible only by the Constitutional Court of Ukraine.

\section{References}

Brian Bicks. Theory of Natural Law. Philosophy of Law; translated from English by P.Tarashcuk. Kyiv: Publishing House of Solomia Pavlychko "Osnovy", 2007. 1254 p.

Convention for the Protection of Human Rights and Fundamental Freedoms ratified by the Law of 17.07.1997 No. 475/97-BP. (Edition as of 02.10.2013). Legislation of Ukraine [Official web site] URL: http://zakon1.rada.gov.ua/laws/show/995 004.

Dzhabrailov. R. A. Principle of Justice as a Basis for Transformation of the Economic and Legal System of the State. Journal of the National Academy of Science of Ukraine. 2017. No.7. P. 74-80.

Fuller L. Morality of Law; translated from English by T. Danilova, Moscow; Cheliabinsk : IRISEN, Socium, 2016. $308 \mathrm{p}$.

General Theory of Law: Textbook/ Under general edition of M. I. Kozyubra. - K.: Vaite, 2016. 392 p.

Hoffe Otfried. Justice: Philosophic Introduction / Translated from German O.V.Kidyushova edited by T. A. Dmitrieva. - M., 2007. 192 p.

Ivanyuta N. V. Functions of the Commercial Procedural Law: Theoretical and Practical Aspects : Monograph. Odessa : Feniks, 2018. 516 P.

Jurisprudence: Philosophical and Theoretical Understanding: a Collective Monograph / A. M. Bernyukov, V. S. Bigun, Yu. P. Loboda, B. V. Malyshev, S. P. Pogrebniak, S. P. Rabinovych, V. S. Smorodynsky, O. V. Stovba / (Responsible editor V.S.Bigun). - Kyiv, 2009. 316 p. (Library of International Journal "Problems of Philosophy of Law").

Justinian's Digests: Translated from Latin / Responsible editor L. L. Kofanov - M., 2002. V. 1. Books I-IV.

Kelsen H. Pure Theory of Law. With amendment: The problem of Justice; translated from German by O. Mokrovsky. Kyiv: Univers, 2004. 496 p.

Kolodiy A. M. Principles of Law of Ukraine: Monograph. K.: Yurynkom, Inter, 1998. P. 27.

Koverznev V. O. Economic and Legal Support of Cooperation in Ukraine: Monograph / The National Academy of Science of Ukraine. Institute of Economic and Legal Research. Chernihiv: LLC "Publishing House Poligraf", 2017. 383 p.

Koverznev V. O. Characteristics of Individual Foundations (Principles) of Economic Litigation. The first scientific readings in the memory of Academician V. K. Mamutov: materials of the round table (February 8, 2019, Kyiv). Scientific edition by V. A. Ustymenko. The National Academy of Science of Ukraine, Institute of Economic and Legal Research, 2019. 264 p.

Kozellek R. Time Layers. Research on the History Theory: Translated from German. — K., 2006. 436 p.

Nersesiants V.S. Philosophy of Law. Textbook for universities. - M.: Publishing group INFA-M - NORMA. 1997. $652 \mathrm{p}$.

Savigny F. C. v., Vom Beruf unserer Zeit fur Gesetzgebung und Rechtswissenschaft, 1814. 355 p.

Spranger E. Lebensformen. Geistwissenschaftliche Psychologie. Halle: Niemeyer, 1914. S. 416-522 p. 
The Commercial Procedure Code of Ukraine dated 01.11.1991 No. 1798-XII (as subsequently amended). Information of the Verkhorna Rada of Ukraine. 1992. No. 6. Art. 56.

The Commercial Code of Ukraine dated 16.01.2003 № 436-IV (as subsequently amended) Information of the Verkhovna Rada of Ukraine. 2003. No. 18, No.19-20, No. 21-22. Art 144.

The Constitution of Ukraine: Adopted on the fifth session of the Verkhovna Rada of Ukraine dated June 28, 1996 (as subsequently amended). Information of the Verkhorna Rada of Ukraine. 1996. No. 30. Art. 141. 